\title{
Investigation on Behavior of Castellated Composite Beams under Fire
}

\author{
Yuhan Wang ${ }^{1, *}$, Lianguang $\mathrm{Jia}^{1}$, Xuefeng $\mathrm{Li}^{2}$ \\ ${ }^{1}$ School of Civil Engineering, Shenyang Jianzhu University,No.9,Hunnan Road, Hunnan District, Shenyang City, Liaoning, P.R. China \\ ${ }^{2}$ School of Management, Shenyang Jianzhu University,No.9,Hunnan Road, Hunnan District, Shenyang City, Liaoning, P.R. China
}

\begin{abstract}
This paper is to study the fire resistance of castellated composite beams. Based on experiment, a reasonable castellated composite beam model is established by using finite element software. The critical temperature of castellated composite beams influenced by hole opening ratio, hole pitch, width-thickness ratio of the web and stiffener have been analyzed. The result shows that stiffener has a great influence on the fire resistance of castellated composite beams, which can increase the critical temperature greatly. The width-thickness ratio of the web has some influence on the buckling behavior of castellated composite beams under fire condition. When width-thickness ratio is higher, the web is more prone to buckling failure. The hole opening ratio and hole pitch have a little influence on the fire resistance of castellated composite beams.
\end{abstract}

\section{Introduction}

The castellated composite beam is a composite structure that connects the castellated steel beam to the concrete floor through the shear connector and make them be jointly forced. The most outstanding feature of the castellated composite beam is that it gives full play to the advantages of the concrete floor and the castellated steel beam, and it has good overall performance ${ }^{[1]}$. The holes of the castellated composite beam are convenient for crossing the pipeline, effectively reducing the height of the layer and saving the steel, which have good economic and social benefits ${ }^{[2]}$. While the concrete floor can play the role of improving the fire resistance of the steel beam ${ }^{[3]}$.Compared with the solid composite beams, the holes of the castellated beams not only damage the continuity of the web, but also cause the temperature of the web between the holes to be higher. This is due to the holes on surface are exposed to high temperature, so the web has more contact area with the hot air. The web of the castellated composite beam are more susceptible to buckling failure and have a significant impact on the bearing capacity of the structure.

The mechanical properties of steel structures under fire have been intensively investigated ${ }^{[4-8]}$, and the corresponding fire resistance design methods have been adopted in the code ${ }^{[9]}$. However, little is known about the fire resistance of castellated steel structures. The finite element models such as that conducted by Ellobody et al. ${ }^{[10]}$ have shown that load ratios and steel grades influence the fire resistance and behavior of composite castellated beams with profiled steel sheeting. Bihina [11] conducted fire tests on circular hole castellated composite beams and analyzes the temperature distribution of concrete floors, beam flanges and webs. Wang et al ${ }^{[12]-[14]}$ conducted a finite element analysis of the buckling behavior of the castellated composite beam with rounded polygons under fire and pointed out that the castellated beam under fire are more prone to buckling failure to the webs due to the faster web heating rate. Wang used a modified barometric model to predict the web buckling failure temperature of castellated beams under fire. In this paper, fire-resistant performance of solid composite beam, circular castellated composite beam and regular hexagonal composite castellated beam are studied. The finite element software ABAQUS is used to establish the analysis model of castellated composite beam under the condition of increasing temperature. The purpose of this study is to assess the effect of hole opening ratio, hole pitch, width-thickness ratio and stiffener on critical temperature, and to provide references for the fire resistance design of castellated steel structures.

\section{Castellated beam fire tests}

\subsection{Specimen details}

To examine the effect of hole pattern on the fire resistance of composite beams, three H-shaped composite beams are designed and tested. They are solid composite beams, circular hole castellated composite beams and hexagonal castellated composite beams, respectively. The cross-sectional dimensions of the specimens are designed according to the "Application Manual of Hot-Rolled H-Beam Design". The specimens are numbered L1, L2 and L3 according to the different

* Corresponding author: Yuhan Wang: 942158233@qq.com 
hole pattern. The parameters of composite beams and Concrete floor are shown in Table 1 and Table 2. The sketch of the specimen is shown in Figure 1 (taking the circular hole castellated beam as an example). To understand the mechanical properties of the materials used in the test at room temperature, the steel and concrete test cubes are tested for their properties. The type of steel used in the test piece is Q345, and the steel is made into standard steel plate specimens according to "Metallic materials_-Tensile testing_-Part 1:Method of test at room temperature" ${ }^{[15]}$.Steel plates are divided into two groups according to their thicknesses, which are $4 \mathrm{~mm}$ and $6 \mathrm{~mm}$, respectively. Each group has 3 test pieces. A total of 6 test pieces are tested to obtain the yield strength $f_{y}$, ultimate strength $f_{u}$ and elastic modulus
E of the steel, as shown in Table 3. The concrete strength grade is $\mathrm{C} 30$. Vibrators are used to vibrate the concrete during pouring. After the initial setting of the concrete, watering curing is performed, and the curing period is 28 days. The steel girder and concrete floor resist the slip between the contact surface through the cylindrical head pegs. The design of the stud refers to "Code for Design of Composite Structures" ${ }^{[16]}$. Stud diameter is $13 \mathrm{~mm}$. The vertical spacing of studs is $85 \mathrm{~mm}$, and lateral spacing is $55 \mathrm{~mm}$. A total of 36 studs are arranged. Reinforced HRB400 steel bars are placed in the concrete floor. The longitudinal reinforcement diameter is $8 \mathrm{~mm}$, its spacing is $200 \mathrm{~mm}$, and the total number is 4 . The transverse reinforcement diameter is $10 \mathrm{~mm}$, its spacing is $200 \mathrm{~mm}$, and the total number is 9 .

Table 1. The parameters of composite beams.

\begin{tabular}{|c|c|c|c|c|c|c|}
\hline $\begin{array}{c}\text { Experiment } \\
\text {-al model }\end{array}$ & Hole pattern & $\begin{array}{c}\text { Numbers of } \\
\text { hole }\end{array}$ & $\begin{array}{c}\text { Hole opening } \\
\text { ratios }\end{array}$ & $\begin{array}{c}\text { Web size } \\
\text { /mm }\end{array}$ & $\begin{array}{c}\text { Flange } \\
\text { size/mm }\end{array}$ & $\begin{array}{c}\text { Beam } \\
\text { length/mm }\end{array}$ \\
\hline L1 & Solid & - & - & $188 \times 4$ & $100 \times 6$ & 1660 \\
\hline L2 & circular & 6 & $70 \%$ & $188 \times 4$ & $100 \times 6$ & 1660 \\
\hline L3 & hexagon & 6 & $70 \%$ & $188 \times 4$ & $100 \times 6$ & 1660 \\
\hline
\end{tabular}

Table 2. The parameters of concrete floor

\begin{tabular}{|c|c|c|}
\hline Floor size/mm & $\begin{array}{c}\text { Transverse } \\
\text { reinforcement }\end{array}$ & $\begin{array}{c}\text { longitudinal } \\
\text { reinforcement }\end{array}$ \\
\hline $1660 \times 700 \times 60$ & $\varnothing 10 @ 200$ & $\varnothing 10 @ 200$ \\
\hline
\end{tabular}

Table 3. Mechanical properties of steel

\begin{tabular}{|c|c|c|c|}
\hline $\begin{array}{c}\text { Thickness of } \\
\text { steel }\end{array}$ & $\mathbf{f}_{\mathbf{y}}\left(\mathbf{N} / \mathbf{m m}^{\mathbf{2}}\right)$ & $\mathbf{f}_{\mathbf{u}}\left(\mathbf{N} / \mathbf{m m}^{2}\right)$ & $\mathbf{E}\left(\mathbf{1 0}^{\mathbf{5}} \mathbf{N} / \mathbf{m m}^{\mathbf{2}}\right)$ \\
\hline 4 & 333.4 & 551.2 & 2.012 \\
\hline 6 & 329.8 & 549.8 & 1.998 \\
\hline
\end{tabular}

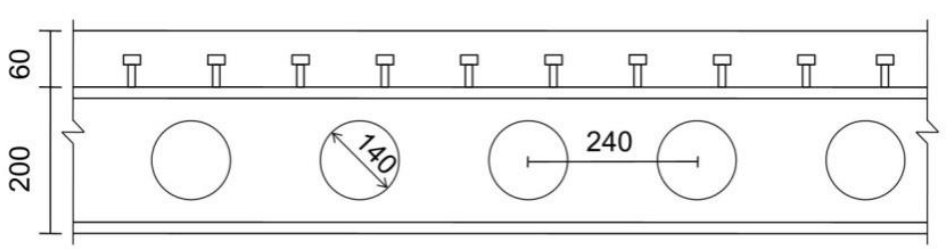

Figure 1. Schematic diagram of circular hole castellated beam(All dimensions are given in meters).

\subsection{Test equipment and test design}

This section uses a circular hole castellated composite beam fire test as an example, and other specimens are similar. Considering of the site, weather condition and other factors, a fire furnace is designed and manufactured to simulate real fire circumstance. The test is carried out in the open space on the west side of the structural test hall of Shenyang Jianzhu University. The size of the fire test furnace is $2.7 \mathrm{~m} \times 1.4 \mathrm{~m} \times 2.25 \mathrm{~m}$ with C30 grade reinforced concrete structure which has a $250 \mathrm{~mm}$ thickness wall. To ensure the temperature in the furnace and every normal device operation during the test, the inside and the around the test furnace are wrapped with aluminum silicate refractory felt mat. The castellated beam specimens are placed on a concretefilled steel tubular column support with a height of $1.7 \mathrm{~m}$. The boundary conditions of composite beams are simply supported on both ends. The column and concrete floor are bolted. The column support is wrapped with a $50 \mathrm{~mm}$ thick fire-resistant mat to improve the fire-resistance of the concrete-filled steel tubular column support. Smoke vents are provided along the wall thickness of the test furnace and are also used to place thermocouples.

This test is to study the influence of the hole pattern on the mechanical properties of the castellated composite beams under fire condition. The test is conducted by 
applying a uniform load and then raising the temperature. Eight $20 \mathrm{~kg}$ single-layer iron blocks are laid on the top of the concrete slab. The total weight of $22.4 \mathrm{kN}$ is evenly distributed along both sides of the composite slab central line. During the loading process, specimens' deformation is observed to ensure the specimens are in an elastic stage. The test was performed when the load is applied to the maximum value and the displacement of the specimen is stable. The test will be stopped when vertical deformation in the mid-span reached 1/20 of the effective span, the deformation is too large and result in the collapse of the stacked test blocks, the collapse of the concrete floor of the three specimens, or other safety issues such as the damage of the test furnace happens. The deformation of the specimens in the process of loading and temperature-increasing is measured by an electronic displacement meter at multiple points. The loading device is shown in Figure 2. The specimen is heated according to ISO 834 standard temperature curve. As shown in Figure 3, the furnace temperature is in consistent with the standard temperature. The maximum temperature in the furnace is about $900 \mathrm{oC}$, and the data have been collected within $60 \mathrm{mins}$. The specimens are exposed to fire on three sides, and K-type armored thermocouples are used to measure the specimens and temperature in furnace. Deformation and temperature measuring points are shown in Figure 4.

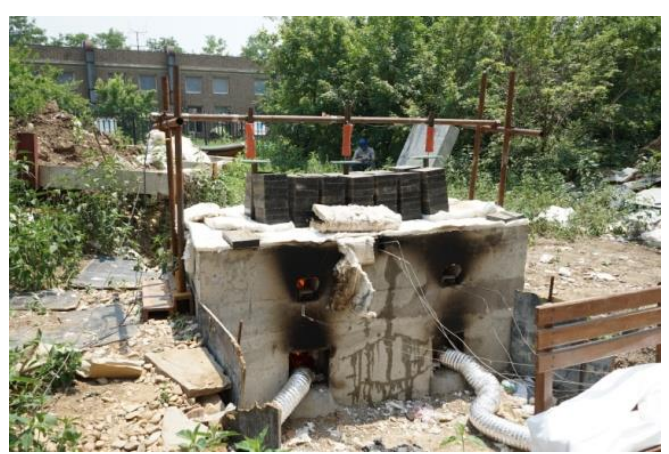

Figure 2. Loading device of test

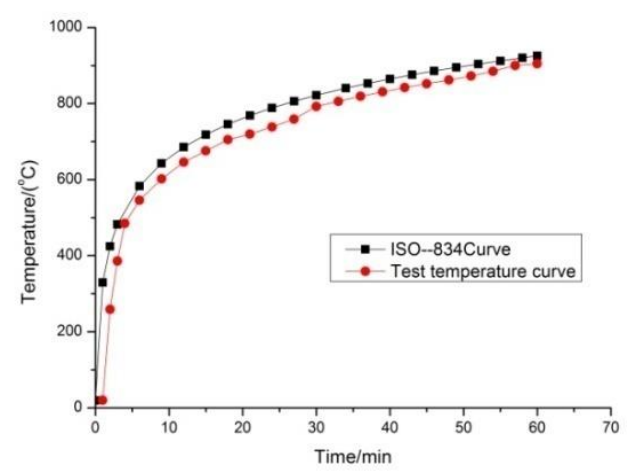

Figure 3. Comparison of temperature in test furnace with ISO 834 standard temperature curve.

|1 Vertical deformation point

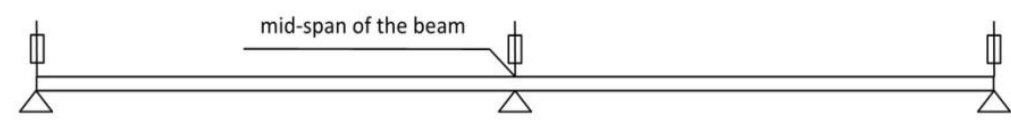

(a)

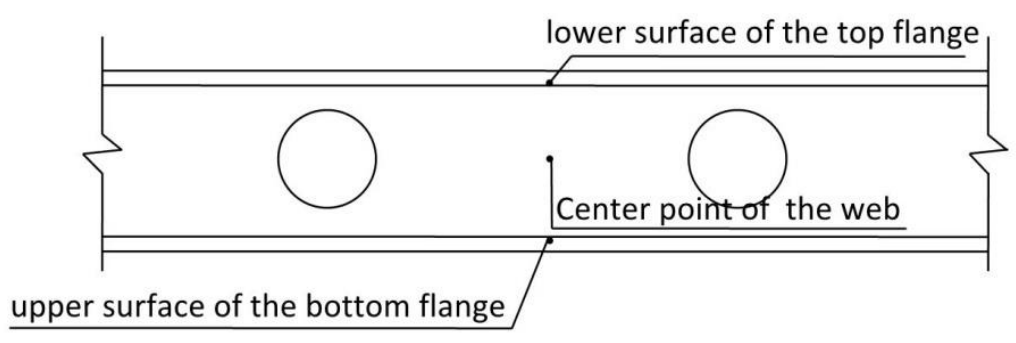

(b)

Figure 4. Schematic diagrams of different types of measuring points.(a) deformation measuring point; (b) Temperature measuring point.

\subsection{Test and result analysis}

Under fire conditions, the displacement changes of specimen L1 (solid web composite beam), specimen L2 (circular hole castellated composite beam) and specimen L3 (regular hexagonal castellated composite beam)are similar with temperature changes. Compared with L1, the temperature increasing rate of specimen L2 and specimen L3 are slower. The deformation of the specimens is not obvious and the increasing rate of midspan displacement is slight before the temperature reaches to $500{ }^{\circ} \mathrm{C}$. The mid-span displacement increases gradually when temperature is between $500{ }^{\circ} \mathrm{C}$ and $750{ }^{\circ} \mathrm{C}$, and the specimens' deformation increases 
obviously. After $750{ }^{\circ} \mathrm{C}$, the mid-span displacement curve begins to steepen rapidly along with temperature increasing. At about $900^{\circ} \mathrm{C}$, the displacement in the midspan reaches to the maximum.

Comparing the destruction form of specimens, it is found that all the specimens are under bending and torsion failure. The maximum deflection of the specimens appear in the mid-span of the beams. The tilt degree of concrete slab under fire is very severe, but there is no collapse. The local warping occurs at both sides of the concrete floor, which causes separating from the castellated beam. Lateral cracks appear on the side and the lower concrete floor surface. Cracks on the side are small and do not penetrate in the thickness direction. There is no crack on the upper surface of the concrete floor. Compared with the specimen L1, the concrete floor of the specimen L2 and the specimen L3 have less cracks.

Obvious lateral torsions can be seen on the bottom flanges of the three composite beams, and S-shape flexion can be presented eventually on the web as well. The composite beam web of specimen L1 deflect laterally. The specimens L2 and L3 occur buckling failure between the holes of the webs, and the specimen L3 is more severe. Specimen L3 tore at the corners of hexagons, and its tearing direction is at $45^{\circ}$. Compared with the specimen L1, the overturning of the lower flange of the specimens L2 and L3 is more severe.

From the test and data analysis, it is found that comparing with the solid composite beam, the castellated composite beams are more prone to buckling failure under the condition of increasing temperature. This is because the opening holes in the web weakens the bearing capacity of the composite beam. And as the temperature increases, the strength and elastic modulus of steels are continuously declining. When the temperature reaches $700^{\circ} \mathrm{C}$, the mechanical properties of steels decline dramatically. These are the two reasons cause the castellated composite beams lose their bearing capacity faster. The hole pattern has a certain impact on the fire resistance of castellated composite beams. Comparing the hexagonal castellated composite beam with the circular hole castellated composite beam, the hexagonal castellated composite beams have less fireresistance than circular hole castellated composite beams because of the stress concentration at the hole corner.

Table 4. The reduction factor of steel at high temperature

\begin{tabular}{|c|c|c|c|c|c|c|c|c|c|c|}
\hline Temperature $^{\circ} \mathrm{C}$ & 20 & 100 & 200 & 300 & 400 & 500 & 600 & 700 & 800 & 900 \\
\hline $\begin{array}{l}\text { Yield strength } \\
\text { reduction } \\
\text { factor of } \\
\text { steel }\left(\mathbf{f}_{\mathrm{y} \mathrm{T}} / \mathbf{f}_{\mathrm{y}}\right)\end{array}$ & 1.000 & 1.000 & 1.000 & 1.000 & 1.000 & 0.780 & 0.470 & 0.230 & 0.110 & 0.060 \\
\hline $\begin{array}{c}\text { Elastic } \\
\text { modulus } \\
\text { reduction } \\
\text { factor of } \\
\text { steel }\left(\mathbf{f}_{\mathrm{pT}} / \mathbf{f}_{\mathrm{y}}\right)\end{array}$ & 1.000 & 1.000 & 0.900 & 0.800 & 0.700 & 0.600 & 0.310 & 0.130 & 0.090 & 0.0675 \\
\hline
\end{tabular}


Table 5. Specific heat capacity and thermal conductivity of steel and concrete at different temperatures.

\begin{tabular}{|c|c|c|c|c|c|c|c|c|c|c|c|}
\hline & Temperature $^{\circ} \mathrm{C}$ & 20 & 100 & 200 & 300 & 400 & 500 & 600 & 700 & 800 & 900 \\
\hline \multirow{2}{*}{ Steel } & $\begin{array}{c}\text { thermal } \\
\text { conductivity } \\
\mathrm{W} /\left(\mathbf{m} \cdot{ }^{\circ} \mathrm{C}\right)\end{array}$ & 53.3 & 50.7 & 47.3 & 41.4 & 39.2 & 37.0 & 34.8 & 32.6 & 30.4 & 28.2 \\
\hline & $\begin{array}{c}\text { Specific heat } \\
\text { capacity } \\
\mathrm{J} / \mathrm{kg} \cdot{ }^{\circ} \mathrm{C}\end{array}$ & 431 & 471 & 522 & 573 & 624 & 675 & 760 & 1008 & 799 & 650 \\
\hline \multirow{2}{*}{ Concrete } & $\begin{array}{c}\text { thermal } \\
\text { conductivity } \\
\mathrm{W} /\left(\mathbf{m} \cdot{ }^{\circ} \mathrm{C}\right)\end{array}$ & 1.36 & 1.35 & 1.34 & 1.32 & 1.22 & 1.10 & 0.97 & 0.85 & 0.72 & 60 \\
\hline & $\begin{array}{c}\text { Specific heat } \\
\text { capacity } \\
\mathrm{J} / \mathrm{kg} \cdot{ }^{\circ} \mathrm{C}\end{array}$ & 913 & 963 & 1022 & 10755 & 1122 & 1164 & 1200 & 1231 & 1256 & 1275 \\
\hline
\end{tabular}

\subsection{Finite element model establishment and validation}

The finite element analysis software is used to establish the castellated composite beam model with three sides exposed to fire. The analysis of fire resistance of castellated composite beam model subjected to dead load under standard heating condition is carried out by means of thermo-mechanical coupling analysis, that is, the model is first carried out under thermal analysis , and then the mechanical analysis is performed by using that results.

\subsubsection{Thermal analysis model establishment}

The unit type of concrete floor and steel beam is C3D8R. To ensure the concrete floor and the castellated steel beam work together, Embedded Region is selected for the stud and the floor. In the contact surface between the upper flange and the concrete slab of the beam, the friction coefficient is defined as 0.3 . Steel is selected as the slave surface. It is assumed that there is a small slip between the steel beam and the concrete floor. In the thermal analysis, the absolute zero is defined as -273.16 , the Stefan-Bolzman constant is $5.67 \times 10^{-8} \mathrm{~W} / \mathrm{m}^{2} \cdot \mathrm{k}^{4}$, and the initial temperature is defined as $25{ }^{\circ} \mathrm{C}$. The thermal convection coefficient is defined as 25 when the composite beam model is heated up. The heat radiation coefficient of the concrete surface is 0.5 and the heat radiation of the steel surface is 0.95 . Although the top surface of the steel beam is in good contact with the concrete surface, small bubbles still exist microscopically. Therefore, the concrete and the steel are not completely in contact with each other, causing a temperature gradient at the interface. The thermal interface coefficient is defined as $0.01 \mathrm{~m}^{2} \cdot{ }^{\circ} \mathrm{C} / \mathrm{W}$.

\subsubsection{Thermo-mechanical coupling model establishment}

Based on thermal analysis model, simply supported constraint is applied to the beam end of castellated composite beam. The temperature stress caused by the axial deformation due to column restraintis not considered in the analysis process. The out-of-plane displacement of web greatly differs from the actual one.
Therefore, limits of out-of-plane displacement on the composite beams are set up.

\subsubsection{Model Validation}

The simulated results are compared with the experimental results. Figure 6 shows the results of the time-temperature curves obtained from the simulations and experiments, and Figure 7 shows the results of midspan displacement. The figures show that the finite element result is coincident with the experimental curve, which proves the effectiveness of this fire resistance analysis model.

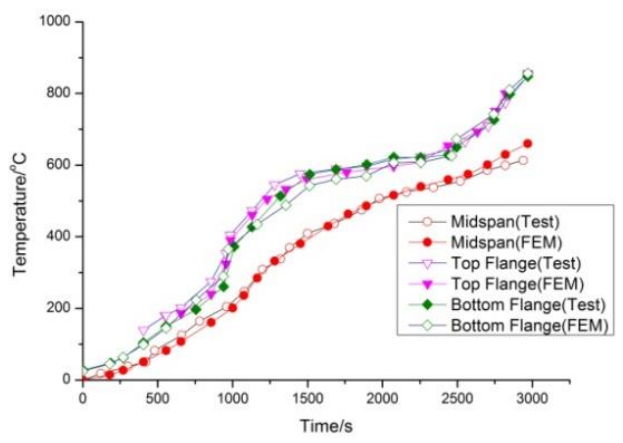

Figure 6. Comparison of the time-temperature curves of finite element model and test

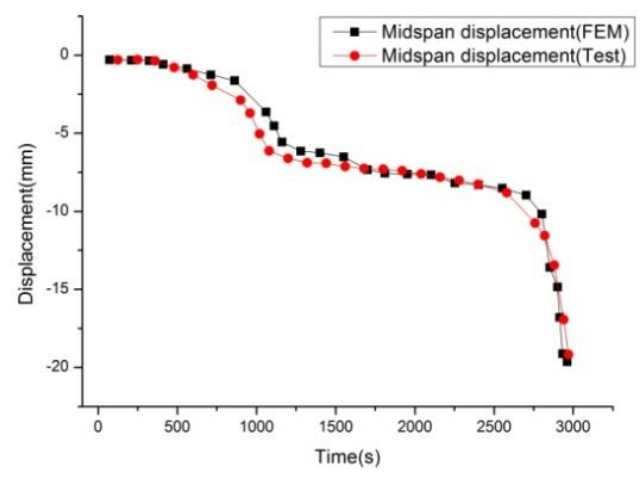

Figure 7. Comparison of the time-displacement curves of finite element model and test 


\section{Parameter analysis}

The influence of hole opening ratio, hole pitch, widththickness ratio of the web and stiffener on the fire resistance of castellated composite beams under the standard temperature conditions are analyzed. Taking the perpendicular displacement that reaches to $1 / 20$ of the beam $\operatorname{span}(\delta=250 \mathrm{~mm})$ as the limit critical state, the castellated composite beams will get to the critical state under fire.

\section{1 hole opening ratio}

The term of hole opening ratio refers to the ration of hole diameter to web cross-section height. The displacementtime curves of circular castellated composite beams with different hole opening ratios at the hole pitch of $0.525 \mathrm{~m}$ are shown in Figure 8. It can be seen from the figure that before the fire resistance $\operatorname{limit}(\delta=250 \mathrm{~mm})$, except for the solid web beam, the difference among the castellated beams' displacement trend is not big. The hole opening ratio has no obvious effect on the fire resistance time. The critical temperature of the castellated beams can be obtained by finite element analysis. The critical temperature degrees of solid web beam and hole opening ratio of $60 \%, 70 \%$ and $80 \%$ are $770{ }^{\circ} \mathrm{C}, 725{ }^{\circ} \mathrm{C}, 716{ }^{\circ} \mathrm{C}$ and $691{ }^{\circ} \mathrm{C}$ respectively. The critical temperature of the solid web beam and the castellated composite beams vary considerably, because the castellated beams have holes in the web that reduce the flexural rigidity of the hole section and increase the heat exchange under the fire condition so that the heating rate of the web is accelerated, Therefore, compared with the solid web composite beam, castellated composite beams' carrying capacity is poor in the fire and the critical temperature is lower. The influence of the hole openings of the composite beam is significant on the critical temperature but the hole opening ratio of the castellated beams has little influence.

\subsection{Hole pitch}

The shear force of the castellated beam is mainly borne by the web. The smaller the hole pitch is, the narrower the web between adjacent holes is, the web between the holes is more prone to buckling failure ${ }^{[18]}$. The fire resistance of castellated composite beams under fire will be affected. When the hole ratio is $70 \%$, the timedisplacement curve of the castellated composite beam with different hole pitches is shown in Figure 9. The fire resistance time of composite beams with hole pitches of $0.6 \mathrm{~m}, 0.525 \mathrm{~m}, 0.42 \mathrm{~m}$ and $0.35 \mathrm{~m}$ respectively (hole number is $8,9,11$ and 13)have nearly no difference, the critical temperatures of the composite beams are $745{ }^{\circ} \mathrm{C}, 716^{\circ} \mathrm{C}, 709{ }^{\circ} \mathrm{C}$, and $702{ }^{\circ} \mathrm{C}$ by comparing the results of finite element analysis. The larger hole pitch is, the lower the critical temperature of the castellated beam is, but the difference of the critical temperature is not obvious because the hole pitch and hole opening ratio are both important parameters that cause the web to be weakened. If only the pole pitch factor is considered, which the critical temperature of the castellated beam cannot significantly be affected. The decrease of the mechanical properties of the steel and concrete has a significant impact on the fire resistance carrying capacity of the castellated beam, which reduce the influence of the hole pitch on the fire resistance.

\subsection{Width-thickness ratio of the web}

The time-displacement curve shown in Figure 10 obtained by analyzing the fire-resistant performance of circular hole castellated composite beams with widththickness ratios of 42, 47, 5463 and 75 respectively, when the heating time is $540 \mathrm{~s}$, the mid-span displacement of castellated beam with width-thickness ratio of 75 increases rapidly and keep going. At the same time, the displacements of the remaining members are relatively smooth. The finite element analysis shows that the critical temperatures of the castellated beams with width-thickness ratios of 42, 47, 54 and 63 and 75 are $756^{\circ} \mathrm{C}, 745^{\circ} \mathrm{C}, 716^{\circ} \mathrm{C}, 699^{\circ} \mathrm{Cand} 630^{\circ} \mathrm{C}$ respectively. The thicker the web between the holes is, the higher the critical temperature of the castellated beam is. The critical temperatures of other beams have nearly no difference except for the castellated beams with a widththickness ratio of 75 . However, the critical temperature difference is $126{ }^{\circ} \mathrm{Cfor}$ the components with widththickness ratios of 75 and 42 . This is because during the heating process the vertical cross-sectional temperature distributes unevenly, the web strength lessens due to the opening hole. The rapid heating rate leads to a fast decreasing in the mechanical properties of the web steel. When the web is too thin, the buckling failure between the holes occurs easily, and this leads the lower part of web and bottom flangesto simultaneous torsion, and the carrying capacity of the component loses. However, when the width-thickness ratio of the castellated webs is very small, the carrying capacity of the webs between the holes is high, webs contribute little to the flexural rigidity of the composite beams so that their influence on the critical temperature is not obvious.

\subsection{Stiffener}

A stiffener is set up for a circular hole castellated composite beam with an opening ratio of $70 \%$ and a $0.6 \mathrm{~m}$ hole pitch. The stiffener thickness is $6 \mathrm{~mm}$ and it is set in the web between the holes shown in Figure 11. The mid-span displacement curves of the web with stiffener and the web with non-stiffener are shown in Figure 12. Two curves are nearly the same before 900 s heating time. The stiffener has no effect on the deformation of the web. When the heating time is between $900 \mathrm{~s}$ and 2000s, the displacement of webs with non-stiffener increases gradually, and the growth rate of that is getting faster and faster than that of web with stiffener. After 2000s, when the temperature increases slightly, the displacement of web with non-stiffener developed rapidly, and the castellated composite beam lost its bearing ability, but web with stiffener still works. From the results of finite element analysis, it can be seen 
that the critical temperatures of the castellated composite beams with non-stiffener is $745{ }^{\circ} \mathrm{C}$ and the castellated composite beams with stiffener is $841{ }^{\circ} \mathrm{C}$. The web with stiffener suffers tensile failure at the first hole bridge beside the stiffener and the flange, and the concrete floor above the hole is crushed. The stiffener remarkably improves bearing capacity of the webs and the fire resistance of the castellated composite beams, and the displacement development of the castellated beams.

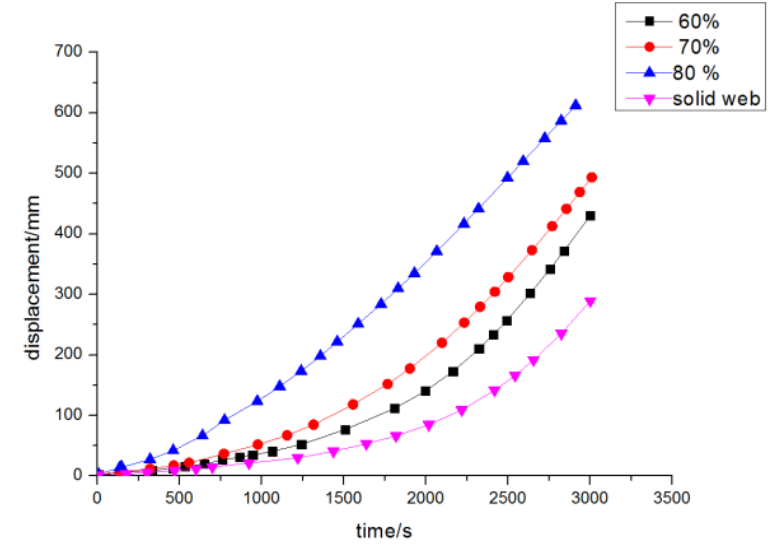

Figure 8. Time -displacement curves for different hole opening ratio

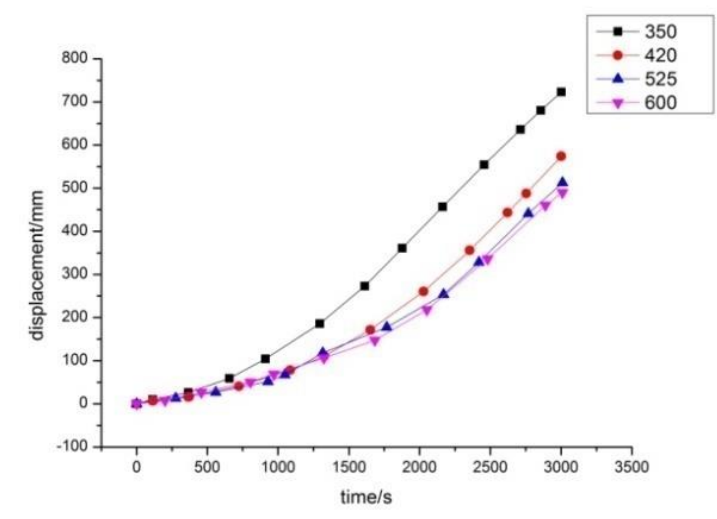

Figure 9. Time -displacement curves for different hole pitch

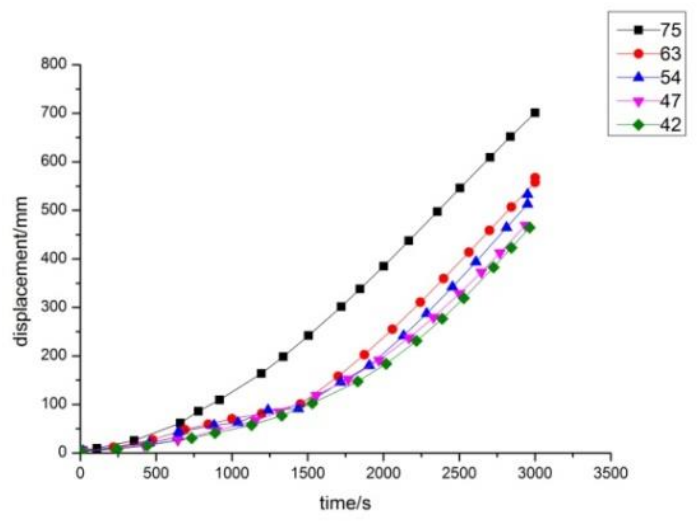

Figure 10. Time -displacement curves for different widththickness ratio

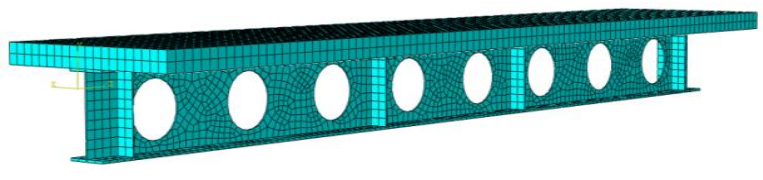

Figure 11. 3-D finite element model of a castellated composite beam with stiffener

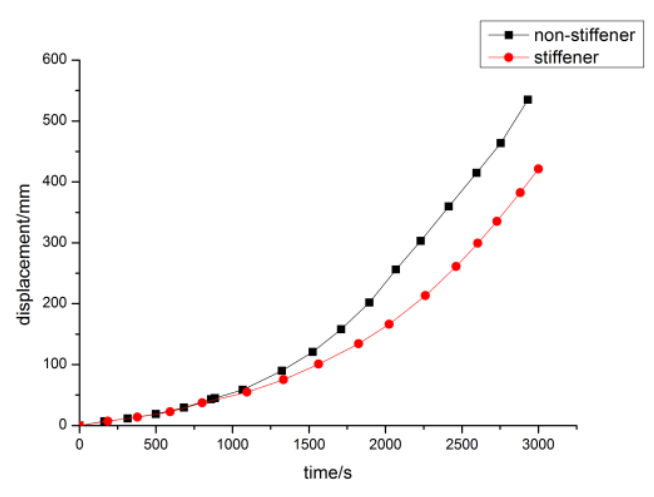

Figure 12. Effect of stiffener on displacement

\section{Conclusions}

The fire resistance of castellated composite beams under standard heating conditions has been studied. The influence of hole opening ratio, hole pitch, web thickness ratio and stiffeners on critical temperature is analyzed. Main conclusions are the following:

(1) During the heating process, the flexural rigidity of the composite beam decreases greatly, and the vertical displacement develops rapidly, causing the web and the bottom flange deflect laterally. The final failure is that castellated beams has large deflection, and buckling deformation occurs in webs, and bottom flange twist.

(2) The hole opening ratio and hole pitch have a little influence on the critical temperature. The smaller the hole opening ratio is, or the bigger hole pitch is, the higher the critical temperature is.

(3) The higher the width-thickness ratio of the web is, the more prone to the web buckling failure is. Stiffener of web have a certain impact on the critical temperature. Stiffener can delay buckling failure of web and bottom flange torsion and improve the fire resistance of castellated composite beams.

\section{Acknowledgments:}

The research was sponsored by the "Liaoning Provincial Natural Science Foundation of China"(Project No. 2015020597).

\section{References}

1. L.G. Jia, M.K. Du, F. Hui, F. Xu, J.Eng.Mech 33,81-87(2016)

2. L.G. Jia, J.H. Yang, Y.F. Liu, 
J.Prog.Steel.Build.Struct 17,24-31(2015)

3. G.Q. Li, W.Y. Wang, H.Y. Zhou, J.Build.Struct 24,35-37(2010)

4. S.X. Guo, G.Q. Li, J.Build.Struct 12,59-61(2005)

5. X. Jiang, G.S. Tong, L. Zhang, J.Har.Inst.Technol 49,68-74(2017)

6. G.Q. Li, J. Ding, R. Zhang, J.Ind.Archit 35,8082(2005)

7. M. Dwaikat, V. Kodur, J.Fire.Technol 46,109128(2010)

8. H. Garcia, M.V. Buezma, J. Cuadrado, A. Orbe,J.Mater.High.Temp30,313-319(2013)

9. Technical Code for Fire Safety of Steel Structure in Buildings. (China Planning Press, 2006)

10. E. Ellobody, B. Young, J.Constr.Steel.Res 113,247260(2015)

11. G. Bihina, B. Zhao, A. Bouchair, J.Eng.Struct 56,2217-2228(2013)

12. P.J. Wang, X.D. Wang, L.L. Zhang, J. Eng. Mech 34, 171-178(2017)

13. H. Li, X.D. Wang, L.L. Zhang,M.Liu,.J.Prog. Build.Steel.Struct 18 . 42-51(2016)

14. X.D. Wang, Investigation on web-post buckling behavior of castellated steel beam with the fillet corner hexagonal web openings in fire. (Available online, http://kns.cnki.net, 2015).

15. Metallic materials-tensile testing-part 1:method of test at room temperature. (International Standardization Organization, 2009)

16. Code for Design of Combined Structures : fire resistant steel. (China Architecture \& Building Press, 2016)

17. Design of steel structures. Part 1-2:General rulesstructural fire design. (European Committee for Standardization,1996)

18. X. Chen, Fire resistance analysis and simplified computing method of restrained cellular beams. (Available online: http://kns.cnki.net, 2016). 